\title{
Probability and Volume of Potential Postwildfire Debris Flows in the 2011 Monument Burn Area, Southeastern Arizona
}

By Barbara C. Ruddy and Kristine L. Verdin

Open-File Report 2011-1181

U.S. Department of the Interior

U.S. Geological Survey 


\section{U.S. Department of the Interior \\ KEN SALAZAR, Secretary}

\section{U.S. Geological Survey \\ Marcia K. McNutt, Director}

U.S. Geological Survey, Reston, Virginia: 2011

For product and ordering information:

World Wide Web: http://www.usgs.gov/pubprod

Telephone: 1-888-ASK-USGS

For more information on the USGS-the Federal source for science about the Earth, its natural and living resources, natural hazards, and the environment:

World Wide Web: http://www.usgs.gov

Telephone: 1-888-ASK-USGS

Suggested citation:

Ruddy, B.C. and Verdin, K.L., 2011, Probability and volume of potential postwildfire debris flows in the 2011 Monument burn area, southeastern Arizona: U.S. Geological Survey Open-File Report 2011-1181, 9 p.

Any use of trade, product, or firm names is for descriptive purposes only and does not imply endorsement by the U.S. Government.

Although this report is in the public domain, permission must be secured from the individual copyright owners to reproduce any copyrighted material contained within this report. 


\section{Contents}

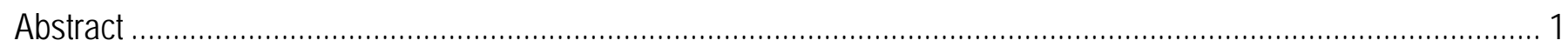

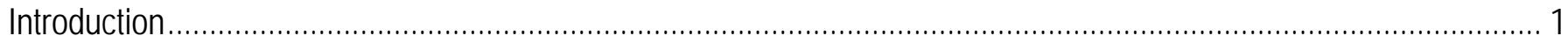

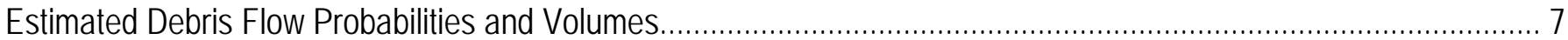

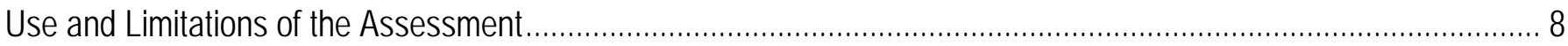

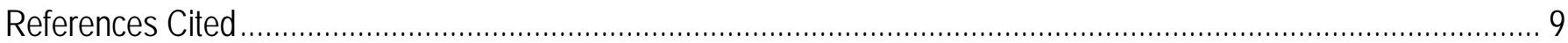

\section{Figures}

1. Location of drainage basins of interest and soil burn severity map of the 2011 Monument burn area, southeastern Arizona.

2. Estimated probability of potential postwildfire debris flows in the 2011 Monument burn area, southeastern Arizona, in response to a 5-year-recurrence, 30-minute-duration rainfall. 3

3. Estimated volumes of potential postwildfire debris flow in the 2011 Monument burn area, southeastern Arizona, in response to a 5-year-recurrence, 30-minute-duration rainfall.

\section{Table}

1. Estimated probabilities and debris-flow volumes for the Monument burn area, southeastern Arizona 


\section{Conversion Factors}

SI to Inch/Pound

\begin{tabular}{lcl}
\hline \multicolumn{1}{c}{ Multiply } & By & \multicolumn{1}{c}{ To obtain } \\
\hline millimeter $(\mathrm{mm})$ & Length & \\
meter $(\mathrm{m})$ & 0.03937 & inch (in.) \\
kilometer $(\mathrm{km})$ & 3.281 & foot $(\mathrm{ft})$ \\
meter $(\mathrm{m})$ & 0.6214 & mile (mi) \\
& 1.094 & yard $(\mathrm{yd})$ \\
\hline square meter $\left(\mathrm{m}^{2}\right)$ & Area & \\
square kilometer $\left(\mathrm{km}^{2}\right)$ & 10.76 & square foot $\left(\mathrm{ft}^{2}\right)$ \\
\hline & 0.3861 & square mile $\left(\mathrm{mi}^{2}\right)$ \\
\hline cubic meter $\left(\mathrm{m}^{3}\right)$ & Volume & \\
cubic meter $\left(\mathrm{m}^{3}\right)$ & 35.31 & cubic foot $\left(\mathrm{ft}^{3}\right)$ \\
cubic meter $\left(\mathrm{m}^{3}\right)$ & 1.308 & cubic yard $\left(\mathrm{yd}^{3}\right)$ \\
\hline & 0.0008107 & acre-foot $(\mathrm{acre}-\mathrm{ft})$ \\
\hline millimeter per year $(\mathrm{mm} / \mathrm{hr})$ & Flow rate & \\
\hline
\end{tabular}

Vertical coordinate information is referenced to the "North American Vertical Datum of 1988 (NAVD 88)" Horizontal coordinate information is referenced to the "North American Datum of 1983 (NAD 83)" 


\title{
Probability and Volume of Potential Postwildfire Debris Flows in the 2011 Monument Burn Area, Southeastern Arizona
}

By Barbara C. Ruddy and Kristine L. Verdin

\begin{abstract}
This report presents a preliminary emergency assessment of the debris-flow hazards from drainage basins burned by the Monument wildfire in southeastern Arizona, in 2011. Empirical models derived from statistical evaluation of data collected from recently burned drainage basins throughout the intermountain Western United States were used to estimate the probability of debris-flow occurrence and volumes of debris flows for selected drainage basins. Input for the models include measures of burn severity, topographic characteristics, soil properties, and rainfall total and intensity for a (1) 2-yearrecurrence, 30-minute-duration rainfall, (2) 5-year-recurrence, 30-minute-duration rainfall, and (3) 10year-recurrence, 30-minute-duration rainfall.

Estimated debris-flow probabilities in the drainage basins of interest ranged from a low of 26 percent in response to the 2-year-recurrence, 30-minute-duration rainfall to 100 percent in response to the 10 -year-recurrence, 30 -minute-duration rainfall. The high probabilities in all modeled drainage basins are likely due to the abundance of steep hillslopes and the extensive areas burned at moderately to high severities. The estimated volumes ranged from a low of about 2,000 cubic meters to a high of greater than 200,000 cubic meters.

\section{Introduction}

The objective of this report is to present a preliminary emergency assessment of the debris-flow hazards from drainage basins burned by the Monument wildfire in southeastern Arizona, in 2011 (figs. 1, 2, and 3, table 1). Debris flows, fast-moving slurries of sediment and water, have been documented after many wildfires in the western United States (Cannon and others, 2010) and can threaten lives, property, infrastructure, aquatic habitats, and water supplies. Wildfires can denude hillslopes of vegetation and can change soil properties that affect watershed hydrology and sediment-transport processes. Even small postwildfire rainstorms can increase overland runoff that erodes soil, rock, ash, and vegetative debris from hillslopes (Cannon and others, 2008). This increased runoff concentrates in stream channels and entrains additional sediment that can lead to the generation of destructive debris flows. Debris flow hazards are most significant 1 to 3 years following wildfires (Susan Cannon, U.S. Geological Survey, written commun., 2010).

Debris flows have been documented in parts of the burned area where wildfires have occurred in the past (1977 in the Miller Creek drainage and 1988 in Ash Canyon) (Wohl and Pearthree, 1991). In addition, on July 10, 2011, a postwildfire debris flow occurred in the Miller Creek drainage (Ann Youberg, Arizona Geological Survey, written commun., 2011).
\end{abstract}




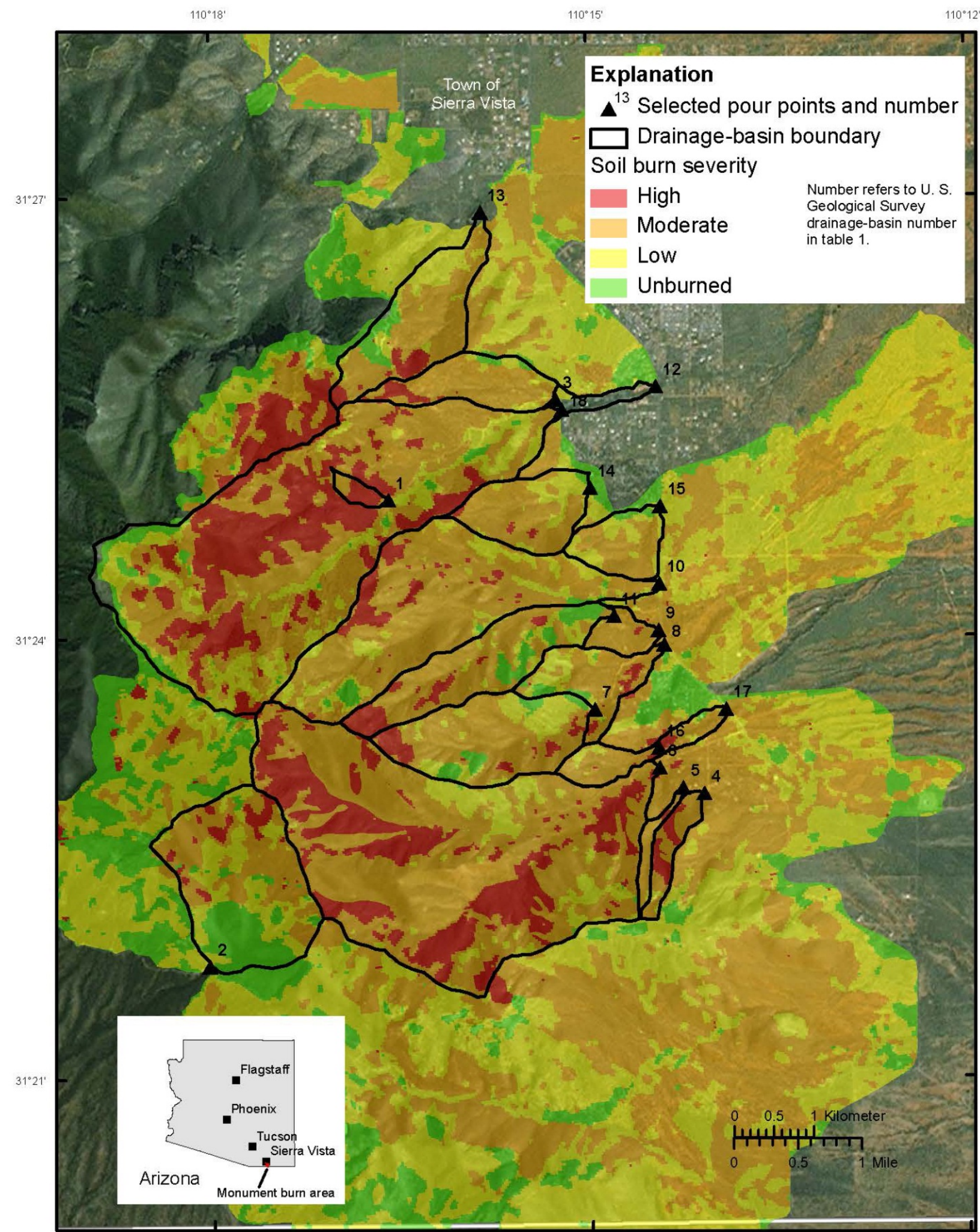

Base from 2007 i cubed. Boundaries and transportation: 2006, ESRI

Figure 1. Location of drainage basins of interest and soil burn severity map of the 2011 Monument burn area, southeastern Arizona. 


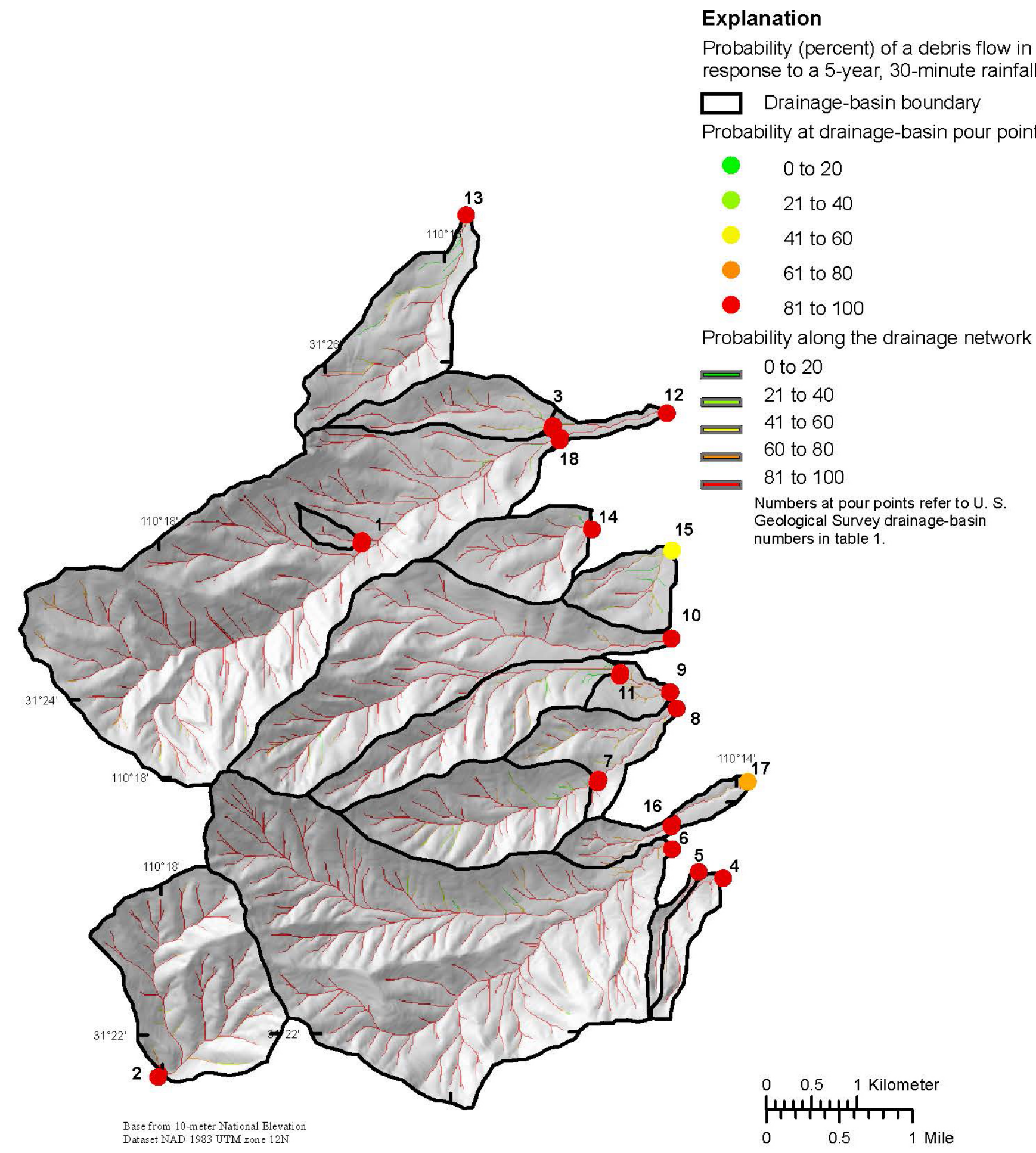

Figure 2. Estimated probability of potential postwildfire debris flows in the 2011 Monument burn area, southeastern Arizona, in response to a 5-year-recurrence, 30-minute-duration rainfall. 


\section{Explanation}

Estimated volume of a debris flow (cubic meters) in response to a

5-year, 30-minute rainfall

Volume at drainage-basin pour point

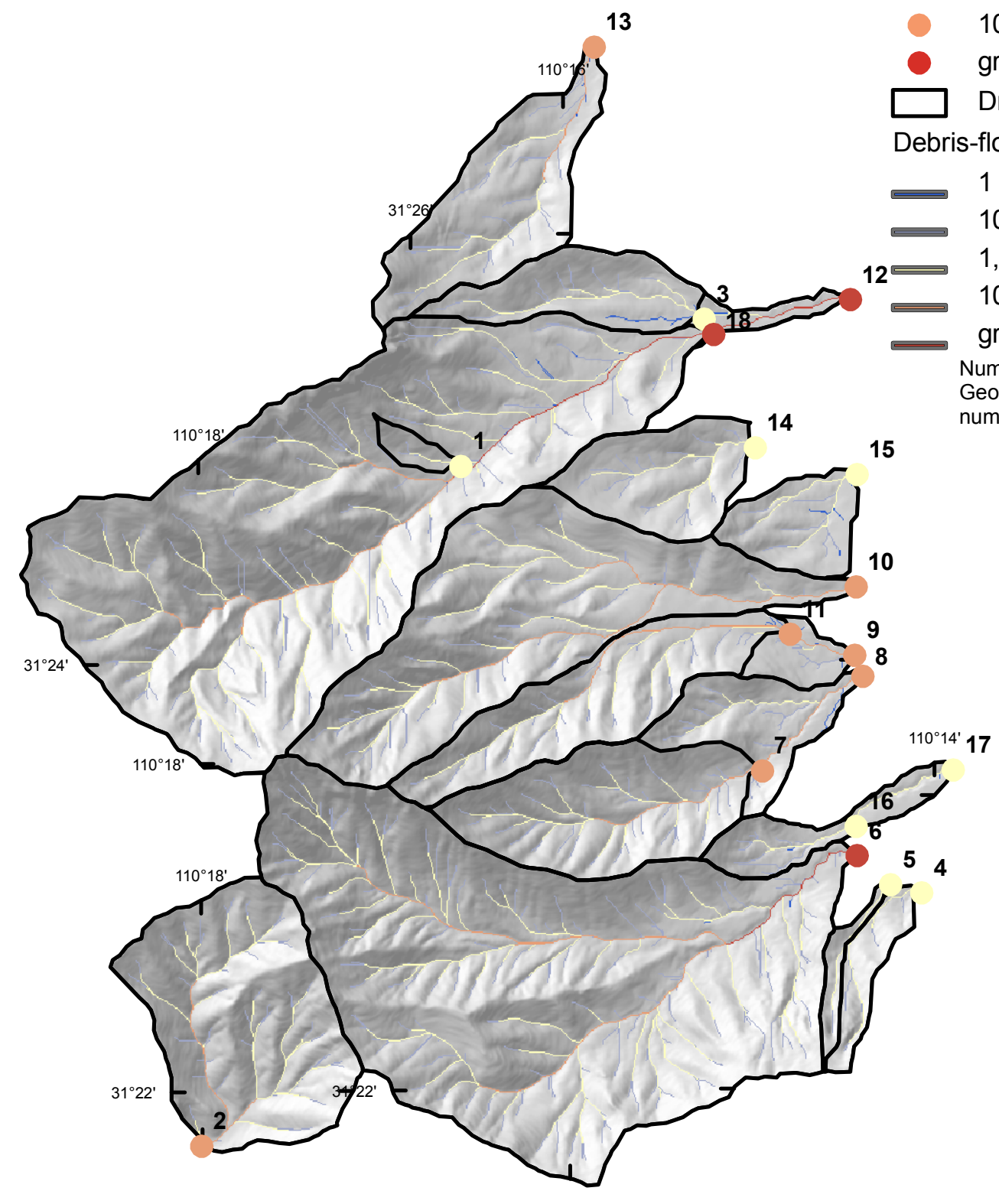

101 to 1,000

1,101 to 10,000

10,001 to 100,000

greater than 100,001

Drainage-basin boundaries

ebris-flow volume along the drainage

1 to 100 network

101 to 1,000

1,001 to 10,000

10,001 to 100,000

greater than 100,001

Numbers at pour points refer to U.S. Geological Survey drainage-basin numbers in table 1.

Base from 10-meter National Elevation Dataset NAD 1983 UTM zone 12N

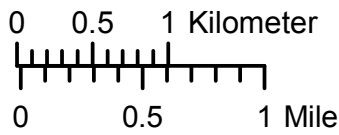

Figure 3. Estimated volumes of potential postwildfire debris flow in the 2011 Monument burn area, southeastern Arizona, in response to a 5-year-recurrence, 30-minute-duration rainfall. 
Table 1. Estimated probabilities and debris flow volumes for the Monument burn area, southeastern Arizona.

[BAER, burned area emergency response; USGS, United States Geological Survey; na, not assigned]

\begin{tabular}{|c|c|c|c|c|c|c|c|c|c|c|c|}
\hline \multirow[t]{2}{*}{$\begin{array}{l}\text { BAER drainage- } \\
\text { basin number for } \\
\text { pour point }\end{array}$} & \multirow[t]{2}{*}{$\begin{array}{l}\text { USGS drainage- } \\
\text { basin number } \\
\text { for pour point } \\
\text { (fig. 1-3) }\end{array}$} & \multirow[t]{2}{*}{ BAER Description } & \multirow{2}{*}{$\begin{array}{c}\text { Area } \\
\begin{array}{c}\text { square } \\
\text { kilometers }\end{array}\end{array}$} & \multirow{2}{*}{$\begin{array}{l}\text { Latitude } \\
\text { degrees, } \\
\text { minutes, } \\
\text { seconds }\end{array}$} & \multirow{2}{*}{$\begin{array}{l}\text { Longitude } \\
\text { degrees, } \\
\text { minutes, } \\
\text { seconds }\end{array}$} & \multicolumn{2}{|c|}{$\begin{array}{c}\text { Debris flow in response } \\
\text { to a 2-year, } 30 \text {-minute } \\
\text { rainfall }\end{array}$} & \multicolumn{2}{|c|}{$\begin{array}{c}\text { Debris flow in response } \\
\text { to a } 5 \text {-year, } 30 \text {-minute } \\
\text { rainfall }\end{array}$} & \multicolumn{2}{|c|}{$\begin{array}{c}\text { Debris flow in response } \\
\text { to a } 10 \text {-year, } 30 \text {-minute } \\
\text { rainfall }\end{array}$} \\
\hline & & & & & & $\begin{array}{c}\text { Probability } \\
\text { (percent) }\end{array}$ & $\begin{array}{l}\text { Volume } \\
\text { (cubic } \\
\text { meters) }\end{array}$ & $\begin{array}{c}\text { Probability } \\
\text { (percent) }\end{array}$ & $\begin{array}{l}\text { Volume } \\
\text { (cubic } \\
\text { meters) }\end{array}$ & $\begin{array}{c}\text { Probability } \\
\text { (percent) }\end{array}$ & $\begin{array}{l}\text { Volume } \\
\text { (cubic } \\
\text { meters) }\end{array}$ \\
\hline 1 & 1 & Pond on private land & 0.16 & $31^{\circ} 24^{\prime} 57^{\prime \prime}$ & $110^{\circ} 16^{\prime} 36^{\prime \prime}$ & 98 & 2,080 & 99 & 2,430 & 100 & 2,680 \\
\hline 4 & 2 & Large Wash with Steel Retainer Wall holding the road in place & 3.28 & $31^{\circ} 21^{\prime} 45^{\prime \prime}$ & $110^{\circ} 18^{\prime} 01^{\prime \prime}$ & 95 & 28,000 & 99 & 32,900 & 100 & 36,500 \\
\hline 8 & 3 & First culvert on this road which has major drainage potential & 1.14 & $31^{\circ} 25^{\prime} 38^{\prime \prime}$ & $110^{\circ} 15^{\prime} 12^{\prime \prime}$ & 81 & 7,280 & 93 & 8,400 & 97 & 9,240 \\
\hline 20 & 4 & Ash Canyon Creek tributary & 0.46 & $31^{\circ} 22^{\prime} 55^{\prime \prime}$ & $110^{\circ} 14^{\prime} 07^{\prime \prime}$ & 96 & 4,480 & 99 & 5,180 & 99 & 5,690 \\
\hline 21 & 5 & Ash Canyon Creek tributary crossing Prince Placer Road & 0.22 & $31^{\circ} 22^{\prime} 58^{\prime \prime}$ & $110^{\circ} 14^{\prime} 15^{\prime \prime}$ & 93 & 2,370 & 98 & 2,750 & 99 & 3,020 \\
\hline 22 & 6 & Ash Canyon Creek 2 & 1.07 & $31^{\circ} 23^{\prime} 06^{\prime \prime}$ & $110^{\circ} 14^{\prime} 27^{\prime \prime}$ & 98 & 170,000 & 99 & 196,000 & 100 & 216,000 \\
\hline 25 & 7 & Stump Canyon Creek & 2.28 & $31^{\circ} 23^{\prime} 29^{\prime \prime}$ & $110^{\circ} 14^{\prime} 57^{\prime \prime}$ & 95 & 19,800 & 98 & 22,900 & 99 & 25,200 \\
\hline 26 & $8^{\mathrm{a}}$ & Stump Canyon Dreek crossing Highway 92 & 3.33 & $31^{\circ} 23^{\prime} 56^{\prime \prime}$ & $110^{\circ} 14^{\prime} 24^{\prime \prime}$ & 87 & 26,800 & 95 & 30,900 & 98 & 33,900 \\
\hline 27 & $9^{b}$ & Stream crossing Highway 92 & 2.40 & $31^{\circ} 24^{\prime} 02^{\prime \prime}$ & $110^{\circ} 14^{\prime} 27^{\prime \prime}$ & 76 & 18,000 & 91 & 20,700 & 95 & 22,700 \\
\hline 28 & 10 & Hunter Canyon Creek crossing Highway 92 & 4.77 & $31^{\circ} 24^{\prime} 21^{\prime \prime}$ & $110^{\circ} 14^{\prime} 26^{\prime \prime}$ & 89 & 42,600 & 96 & 49,100 & 98 & 53,900 \\
\hline 29 & 11 & Stream Crossing Baumkirchner Road & 2.03 & $31^{\circ} 24^{\prime} 08^{\prime \prime}$ & $110^{\circ} 14^{\prime} 48^{\prime \prime}$ & 84 & 16,100 & 94 & 18,600 & 97 & 20,500 \\
\hline 33 & $12^{\mathrm{c}}$ & Miller Canyon Creek crossing Highway & 12.17 & $31^{\circ} 25^{\prime} 42^{\prime \prime}$ & $110^{\circ} 14^{\prime} 28^{\prime \prime}$ & 92 & 161,000 & 97 & 185,000 & 99 & 203,000 \\
\hline na & 13 & na & 1.95 & $31^{\circ} 26^{\prime} 51^{\prime \prime}$ & $110^{\circ} 15^{\prime} 46^{\prime \prime}$ & 71 & 12,000 & 88 & 13,900 & 94 & 15,200 \\
\hline na & 14 & na & 1.27 & $31^{\circ} 25^{\prime} 03^{\prime \prime}$ & $110^{\circ} 15^{\prime} 01^{\prime \prime}$ & 91 & 8,380 & 97 & 9,660 & 99 & 10,600 \\
\hline na & 15 & na & 0.80 & $31^{\circ} 24^{\prime} 51^{\prime \prime}$ & $110^{\circ} 14^{\prime} 25^{\prime \prime}$ & 26 & 3,780 & 50 & 4,350 & 69 & 4,770 \\
\hline na & 16 & na & 0.43 & $31^{\circ} 23^{\prime} 14^{\prime \prime}$ & $110^{\circ} 14^{\prime} 27^{\prime \prime}$ & 66 & 3,140 & 86 & 3,630 & 93 & 3,990 \\
\hline na & $17^{\mathrm{d}}$ & na & 0.66 & $31^{\circ} 23^{\prime} 31^{\prime \prime}$ & $110^{\circ} 13^{\prime} 55^{\prime \prime}$ & 46 & 3,440 & 71 & 3,970 & 84 & 4,360 \\
\hline na & $18^{e}$ & na & 10.80 & $31^{\circ} 25^{\prime} 33^{\prime \prime}$ & $110^{\circ} 15^{\prime} 12^{\prime \prime}$ & 96 & 144,000 & 99 & 167,000 & 99 & 183,000 \\
\hline
\end{tabular}

includes USGS drainage-basin number 7

includes USGS drainage-basin number 11

includes USGS drainage-basin number 1, 3, 18

includes USGS drainage-basin number 16

includes USGS drainage-basin number 1 
This report presents an emergency debris-flow hazards assessment, done by the U. S. Geological Survey in collaboration with the State of Arizona, U. S. Department of Agriculture Forest Service, and the Federal Emergency Management Agency Region IX. Estimates are provided of the predicted probability of occurrence and volume of debris that could flow from 18 drainage-basin outlets in response to three design (or reference) storms: (1) 2-year-recurrence, 30-minute-duration rainfall (25-35 mm, a 50 percent chance in any given year), (2) 5-year-recurrence, 30-minute-duration rainfall (33-45 mm, a 20 percent chance in any given year), and (3) 10-year-recurrence, 30-minute-duration rainfall (38-52 mm, a 10 percent chance in any given year). The procedures used for this report are based on the work by Cannon and others (2007; 2010) and Ruddy and others (2010).

A set of empirical equations (models) developed by Cannon and others (2010) and derived from statistical evaluation of data collected from recently burned drainage basins throughout the intermountain western United States were used to estimate the probability of debris-flow occurrence and volumes of debris flows for selected drainage basins. The regression equation (eq. 1) of debris-flow probability is based on empirical data described by Cannon and others (2010, model A). The model for debris-flow probability is as follows:

$$
P=e^{x} /\left(1+e^{x}\right)
$$

where $P$ is the probability of debris-flow occurrence in fractional form; and

$$
x=-0.7+0.03(\% S G 30)-1.6(R)+0.06(\% A B)+0.07(I)+0.2(\% C)-0.4(L L)
$$

where, percent;

\%SG30 is the percentage of the drainage basin area with slope equal to or greater than 30

$R$ is drainage basin ruggedness, the change in drainage basin elevation (meters) divided by the square root of the drainage basin area (square meters) (Melton, 1965);

$\% A B$ is the percentage of drainage-basin area burned at moderate and high severity (data for this investigation from Dave Young, U.S. Department of Agriculture Forest Service, written commun., 2011);

I is average storm intensity (calculated by dividing total storm rainfall [Mike McLane, National Weather Service, written commun., 2011] by the storm duration, in millimeters per hour);

$\% C$ is clay content of the soil (in percent) (U.S. Department of Agriculture, National Resources Conservation Service, 1991, and Schwarz and Alexander, 1995), and

$L L$ is the liquid limit of the soil (percentage of soil moisture by weight) (U.S. Department of Agriculture, National Resources Conservation Service, 1991, and Schwarz and Alexander, 1995).

Cannon and others (2010) also developed an empirical model that can be used to estimate the volume of debris flow that would likely be produced from recently burned drainage basins:

$$
\ln V=7.2+0.6(\ln S G 30)+0.7(A B)^{0.5}+0.2(T)^{0.5}+0.3
$$

where,

$V$ is the debris-flow volume, including water, sediment, and debris (cubic meters);

$S G 30$ is the area of the drainage basin with slopes equal to or greater than 30 percent (square kilometers);

$A B$ is the drainage-basin area burned at moderate to high severity (square kilometers); 
$T$ is the total storm rainfall depth (millimeters); and 0.3 is a bias correction factor that changes the predicted estimate from a median to a mean value (Helsel and Hirsch, 2002).

Each of the 18 drainage basins to be evaluated was identified by a single outlet (pour point) located at the drainage-basin mouth, but some basins are included within larger basins (table 1). Conditions within the drainage-basin area upstream from that pour point were used to estimate debrisflow probability and volume for a specific design storm (Cannon and others, 2010). Locations drainagebasin pour points were identified by the Burned Area Emergency Response (BAER) team for the Monument fire (indicated by USGS drainage-basin numbers in figures 1, 2, and 3 and table 1).

A preliminary map was created using a continuous parameterization technique. With this technique estimates of debris-flow probability and volume (Cannon and others, 2010) were obtained continuously along the drainage network (or flow-direction matrix) (Verdin and Greenlee, 2003; Verdin and Worstell, 2008). This technique was developed as an alternative to traditional basin characterization approaches, which requires "a priori” definition of drainage-basin outlets (pour points) and their corresponding basins.

Using the 1/3-arc-second National Elevation Dataset (Gesch and others, 2002) (10-meter nominal resolution) for the study area and the flow structure inherent in the digital elevation model (DEM), the independent variables driving the probability and volume equations were evaluated for every 10-meter grid cell within the extent of the DEM. Rainfall total and rainfall intensity were calculated from 800-meter precipitation grids provided by the National Weather Service (Mike McLane, National Weather Service, written commun., 2011). Values for all of the independent variables driving the predictive equations were obtained using the continuous parameterization approach in a geographic information system (GIS), although "ruggedness" required a separate ArcGIS program (ESRI, 2009) to evaluate this variable for each grid cell in the study area. Once the surfaces of the independent variables were evaluated for every grid cell within the study area, the probability and volume equations were solved by using map algebra for each location. Identification of the probability or volume of a debris flow at any location within the study area is possible by querying the derived surfaces. For this assessment, a raster sampling technique was used to identify the values of debris-flow probability and volume at selected locations along the drainage network derived from a digital elevation model.

The continuous parameterization technique allows for faster parameter characterization and the ability for characterization upstream from any location, not just predefined basin outlets. The continuous parameterization technique provides a synoptic view of the entire study area which aids in the identification of smaller, high-probability basins within a larger basin. This allows for rapid evaluation of potential "hot spots" within the burned area -- locations with potentially high probabilities of large debris flows. Although modeled probabilities and volumes at the pour point of a predefined basin might be relatively low, locations within the drainage basin might have substantially higher debris flow potential. These can be easily identified with this technique.

\section{Estimated Debris Flow Probabilities and Volumes}

The estimated debris-flow probabilities and volumes in response to the different rainfall scenarios are presented in table 1. Estimated probabilities of debris flows were high for most basins. Conditions in 13 of the 18 basins resulted in debris-flow probabilities greater than 80 percent in response to the 2-year-recurrence, 30-minute-duration rainfall; 16 out of 18 basins in response to the 5year-recurrence; 30-minute-duration rainfall; and 17 out of 18 in response to the 10-year-recurrence, 30minute-duration rainfall. Drainage basin 15 showed the lowest probabilities, which ranged from 26 to 69 percent in response to the 2-year-recurrence, 30-minute-duration rainfall and the 10-year-recurrence, 30- 
minute-duration rainfall, respectively. Debris-flow probabilities for USGS drainage basins 6, 12, and 18 ranged from 92 to 100 percent for 2-year-recurrence, 30-minute-duration rainfall and 10-yearrecurrence, 30-minute-duration rainfall. These high probabilities are likely due to a combination of steep hillslopes burned at moderate and high burn severities, and indicate a potential for substantial debrisflow impacts to any buildings, roads, bridges, culverts, and reservoirs located both within these drainages and immediately downstream from the burned area. However, even small debris flows that affect structures at the basin outlets could cause considerable damage.

Estimated debris-flow volumes ranged from 2,680 m3 for USGS drainage basin 1 to 216,000 m 3 for USGS drainage basin 6 for a 10-year-recurrence, 30-minute-duration rainfall. Estimated debris flow volumes for drainage basins 6, 12, and 18 were at least an order of magnitude greater than those estimated for the 15 other drainage basins. About 90 percent of USGS drainage basin 12 is composed of USGS drainage basin 18. Although larger rainstorms produced estimates of larger debris-flow volume, the increase in estimated volumes for most basins from a 2-year-recurrence, 30-minute-duration rainfall to a 10-year-recurrence, 30-minute-duration rainfall only increased by about 20 percent. A 2-yearrecurrence, 30-minute-duration rainfall (a relatively "small” rainfall amount) is likely to produce a high probability of a debris flow.

An example of the additional detail provided by the continuous parameterization approach is shown in USGS drainage basin 15 on figure 2. While the probability of a debris flow occurring at the pour point of the drainage basin is 50 percent (table 1), the probabilities of a debris flow along the channels upstream from the pour point are much higher. The red channel reaches along the drainage network upstream from the pour point of basin 15 indicate higher debris flow probabilities at these locations with values as high as 81-100 percent.

\section{Use and Limitations of the Assessment}

This assessment presents estimates of debris-flow probability and volume for selected drainage basins in the area burned by the Monument wildfire. Estimates were made in response to three design [or reference] storms: (1) a 2-year-recurrence, 30-minute-duration rainfall (a 50 percent chance in any given year). (2) a 5-year-recurrence, 30-minute-duration rainfall (a 20 percent chance in any given year) and (3) a 10-year-recurrence, 30-minute-duration rainfall (a 10 percent chance in any given year). Larger, less frequent storms are more likely to produce larger debris flows; however, the analyses indicate that even relatively common rainfall events could result in substantial runoff and erosion producing debris flows. Some areas within the selected basins may have higher debris-flow probabilities than those shown at the drainage-basin outlet, or pour point, shown on figure 2, and debris flows may not be produced from all basins during a 2 or 5-year recurrence rainfall. The estimates are meant to be valid for up to 3 years after the wildfire (Susan Cannon, U.S. Geological Survey, written commun., 2010). The maps may be used to prioritize areas where emergency flood warnings or erosion mitigation may be needed prior to rainstorms within these basins, at their outlets, or in areas downstream from these basins. This assessment evaluates only postwildfire debris flows (Cannon and others, 2007). Substantial hazards from flash floods without debris flow may remain for many years after a fire, but are beyond the scope of this analysis.

This analysis is preliminary and is subject to revision. It is being provided owing to the need for timely best science information. The assessment is provided on the condition that neither the U.S. Geological Survey nor the United States Government may be held liable for any damages resulting from the authorized or unauthorized use of the assessment. 


\section{References Cited}

Cannon, S.H., Gartner, J.E., and Michael, J.A., 2007, Methods for the emergency assessment of debrisflow hazards from basins burned by the fires of 2007, southern California: U.S. Geological Survey Open-File Report 2007-1384, 10 p, http://pubs.usgs.gov/of/2007/1384.

Cannon, S.H., Gartner, J.E., Wilson, R.C., and Laber, J.L., 2008, Storm rainfall conditions for floods and debris flows from recently burned areas in southwestern Colorado and southern California: Geomorphology, v. 6, no. 3-4, p. 250-269 doi:10.1019/j.geomorph.2008.03.019.

Cannon, S.H., Gartner, J.E., Rupert, M.G., Michael, J.A., Rea, A.H., and Parrett, C., 2010, Predicting the probability and volume of postwildfire debris flows in the intermountain western United States: Geological Society of America Bulletin, v. 122, p. 127-144.

ESRI, 2009, ArcGIS v. 9.3: Redlands, Calif., ESRI.

Gesch, D., Oimoen, M., Greenlee, S., Nelson, C., Steuck, M., and Tyler, D., 2002, The national elevation dataset: Photogrammetric Engineering and Remote Sensing, v. 68, no. 1, p. 5-11.

Helsel, D.R., and Hirsch, R.M., 2002, Statistical methods in water resources: New York, Elsevier Studies in Environmental Science, v. 49, 529 p.

Melton, M.A., 1965, The geomorphic and paleoclimate significance of alluvial deposits in southern Arizona: Journal of Geology, v. 73, p. 1-38.

Ruddy, B.C., Stevens, M.R., Verdin, K.L., and Elliott, J.G., 2010, Probability and volume of potential postwildfire debris flows in the 2010 Fourmile burn area, Boulder County, Colorado: U.S. Geological Survey Open-File Report 2010-1244, 5 p., http://pubs.usgs.gov/of/2010/1244.

Schwarz, G.E., and Alexander, R.B., 1995, State Soil Geographic (STATSGO) data base for the conterminous United States: U.S. Geological Survey Open-File Report 95-449, http://water.usgs.gov/GIS/metadata/usgswrd/XML/ussoils.xml.

U.S. Department of Agriculture, National Resources Conservation Service, 1991, State Soil Geographic (STATSGO) database-Data use information: Lincoln, Nebr., U.S. Department of Agriculture, National Soil Survey Center, Miscellaneous Publication 1492, 110 p. [Revised July 1994]

Verdin, K.L. and Greenlee, S., 2003, Continuous parameterization using EDNA, in ESRI User's Conference, San Diego, Calif., July 7-11, 2003, Proceedings: Redlands, Calif., ESRI, 9 p., accessed May, 2007, at http://gis.esri.com/library/userconf/proc03/p0617.pdf.

Verdin, K. L. and Worstell, B., 2008, A fully distributed implementation of mean annual streamflow regional regression equations: Journal of the American Water Resources Association, v. 44, no. 6, p. 1537-1547. doi: 10.1111/j.1752-1688.2008.00258.x.

Wohl, E.E., and Pearthree, P.A., 1991, Debris flows as geomorphic agents in the Huachuca Mountains of southeastern Arizona: Geomorphology, v. 4, no. 3-4, p. 273-292. 